\title{
BAHAMIAN ENGLISH OR BAHAMIAN CREOLE? \\ A Socio-historical
}

\author{
Anne Lawlor \\ The Humanities Division \\ The College of The Bahamas
}

(This paper was presented at the Seventh Biennial Conference of the Society of Caribbean Linguistics held in Nassau, The Bahamas at The College of The Bahamas, August 24th - 27th, 1988).

\section{INTRODUCTION}

In this paper I propose to examine particular socio-historical conditions prevailing in the formative years of the Afro-Bahamian contact situation that contributed to the evolution of the Afro-Bahamian speech variety. Through such an investigation I attempt to shed some light on the question posed in the title which seeks to identify the genesis of Afro-Bahamian; more specifically, the question of whether the linguistic system of the Bahamian slave society in the eighteenth century was genetically and topologically related to an English grammar or to an African grammar.

This investigation draws on Alleyne's second-language acquisition and acculturative-process theory which advances the view that

... the Afro-American dialects can be plotted on a scale

representing different degrees of transmission of West

African ellements, and differemtials in degrees of transmission

are to be explained by differences in socio-lingwistic

circumstances in each area (1980).

Under conditions of slavery African speakers were unable to maintain their native languages for any length of time and had to acquire some competence in the dominant European languages of their new environment; this shift from a native to a second language was not uniform and was conditioned largely by the nature of the environment in which they found thernselves.

The crucial factor that determined the underlying structure of the newly acquired system was access to the European model.

Easy access to the European model resulted in a rapid movement through the stages of linguistic acculturization and minimal sustained transmissions from the native African language, in cases obviating a defined creole stage. Restricted access to the European model resulted in a greater number of transmissions from the native African language and thus having the effect of producing a creole system where European forms were superimposed on an underlying African grammar. And further, the acculturative process within a particular locus of contact varied considerably whereby some Africans with greater access to the European Languages developed a linguistic system closer to the European model than others with less access.

A number of socio-historical factors were linguistically significant during the early years of colonization of The Bahama Islands which created a contact situation far removed from that of plantation colonialism in the Caribbean islands. To this end I consider early settlement of the islands, the economic and social organization, the relative distribution of the African and English populations, codes of social interaction and settlement patterns. 
These factors in varying degrees contributed to the distinct acculturative processes resulting in a unique Afro-Bahamian speech variety, locally referred to as Bahamian dialect. Given the archipelagic nature of The Bahama Islands and the relative isolation of one from the other during the eighteenth century, I further consider differences in socio-historical circumstances among the islands that contributed to differences in the emerging linguistic system of the slave society. This investigation is confined to three areas: the northeast islands (Harbour Island and Eleuthera), New Providence and the southeast islands (Cat Island, Exuma, San Salvador, Long Island, Crooked Island and Caicos).

\section{EARLY SETTLEMENT $1648-1783$ Northeast Islands}

The northeast islands of Eleuthera and Harbour Island were settled in 1648 by seventy English Puritans from Bermuda and the island of New Providence in 1666 by Bermudian seamen. Sustained settlement and economic development were fraught with problems arising from poor soils and frequent depredations by the Spanish and French governors of dubious character. In a series of Spanish incursions on New Providence in the early 1700s, the Spaniards carried away all the slaves and burnt down the town. Most of the inhabitants left and settled in other islands and the American colonies. Hereafter the town of Nassau in New Providence became a pirates' republic until the appointment of the first Royal Governor in 1918 who successfully expelled the pirates and encouraged settlers by the offer of land grants.

This period of history was one of extreme poverty and everyone, both colonists and slaves, was engaged in a struggle to survive. Most of the colonists, especially the Bermudians, earned a living from seafaring activities such as wrecking, privateering, trading and fishing and other colonists from England and to a lesser degree from the Caribbean eked a living from small-scale farming, wood-cutting and saltraking. In times of war, the islands enjoyed intervals of prosperity from privateering and illicit trade and in times of peace, domestic discord prevailed. Never in the history of The Bahamas did the economy achieve the critical mass necessary to warrant wholesale importation of slaves as did the classical plantation societies in the Caribbean where massive imports of multi-lingual African slaves repeatedly swamped the ruling monolingual European minority.

However a slave society was established as early as 1656 when "some troublesome slaves, native Bermudians and all the free Negroes were sent into exile at Eleuthera" (Albury 1975). New England and Virginia used the colony for the same purpose. After New Providence was resettled, imports came directly by way of private trade from Africa and thereafter by way of the Caribbean and the southern mainland colonies. But overall these imports were small compared to the thousands that entered the Caribbean region and southern mainland colonies annually.

Table I illustrates the population growth and the relative distribution of the black and white population for the years $1721-1783$. 


\section{TABLE I}

\section{Population Growth of The Bahamas 1721 - 1783}

$((\%)$ marks relative proportion of black and white population of total population for each island).

\begin{tabular}{|c|c|c|c|c|c|}
\hline Source & Year & Island & White & Black & Total \\
\hline \multirow[t]{2}{*}{$\begin{array}{l}\mathrm{CO} \\
23 / 1 / 103\end{array}$} & 1721 & $\begin{array}{l}\text { New Prov. } \\
\text { Harbour Isl } \\
\text { Eleuthera } \\
\text { (Cat Isl) }\end{array}$ & $\begin{array}{l}470(67 \%) \\
124(96 \%) \\
150(82 \%) \\
(12)\end{array}$ & $\begin{array}{l}233(33 \%) \\
5(4 \%) \\
34(18 \%) \\
(3)\end{array}$ & $\begin{array}{l}703 \\
129 \\
184 \\
(15)\end{array}$ \\
\hline & & Total & 756 & 275 & 1031 \\
\hline \multirow[t]{2}{*}{$\begin{array}{l}\text { Saunders } \\
1985\end{array}$} & 1734 & $\begin{array}{l}\text { New Prov. } \\
\text { Harbour Isl. } \\
\text { Eleuthera }\end{array}$ & $\begin{array}{l}461(47 \%) \\
151(94 \%) \\
198(84 \%)\end{array}$ & $\begin{array}{c}* 520(53 \%) \\
10(6 \%) \\
38(16 \%)\end{array}$ & $\begin{array}{l}981 \\
161 \\
236\end{array}$ \\
\hline & & Total & 810 & 568 & 1378 \\
\hline \multirow[t]{2}{*}{$\begin{array}{l}\text { Saunders } \\
1985\end{array}$} & 1744 & $\begin{array}{l}\text { New Prov. } \\
\text { Harbour Isl. } \\
\text { Eleuthera }\end{array}$ & $\begin{array}{l}999(51 \%) \\
-\end{array}$ & $\begin{array}{l}964(49 \%) \\
240\end{array}$ & $\begin{array}{r}1963 \\
240\end{array}$ \\
\hline & & Total & 999 & 1204 & 2203 \\
\hline \multirow[t]{2}{*}{$\begin{array}{l}\text { Craton } \\
(1986)\end{array}$} & 1783 & $\begin{array}{l}\text { New Prov. } \\
\text { Harbour Isl. } \\
\text { Eleuthera }\end{array}$ & $\begin{array}{l}755(30 \%) \\
360(711 / 2) \\
476(60 \%)\end{array}$ & $\begin{array}{c}1739(70 \%) \\
144(281 / 2) \\
310(40 \%)\end{array}$ & $\begin{array}{r}2494 \\
504 \\
786\end{array}$ \\
\hline & & Total & 1591 & 2193 & 3784 \\
\hline
\end{tabular}

*slaves 443 free blacks 77

These figures show a very slow rate of population growth for New Providence and more so for the northeast islands of Harbour Island and Eleuthera, settled since 1648. The demographic ratio of black to white was quite different for the two areas. After one hundred and thirty five years of settlement, the northeast islands had a predominantly white population although the rate of growth was higher for the black population. In New Providence the white and black populations achieved a relatively equal balance after sixteen years of settlement, which was maintained for ten years, and by 1783 the black population constituted $70 \%$ of the total population of New Providence, reflecting a very high rate of increase.

Based on sheer population counts and the demographic ratio of black to white, the linguistic acculturization processes for the two areas must have been very different. Irrespective of the social codes that determined the degree of interaction between the two races, it is clear that the free blacks and the slaves in the northeast islands up to 1734 had ample access to the English dialect spoken by the Bermudian Puritans and their descendants. They lived in very small settlements and made a living from fishing, farm- 
ing, wood-cutting and wrecking, and like any minority group in a new linguistic environment, they would have acquired English in a relatively short space of time. If we take into account the fact that by 1788 the black population of Eleuthera was described as "mostly free people of colour" (Whylly 1789), and by 1834 Eleuthera as an unit had the highest rate of miscegenation (13.09\%) in all the islands (see Saunders 1985), it would indicate a social climate with high levels of interaction between the races affording the black minority unrestricted access to the English dialect of the colonists.

The relative distribution of the migrant populations in New Providence is very similar to that of Barbados where white and black populations were equally balanced twenty five years after colonization and Hancock (1980) argues the case

\section{... in 1650 there were nearly as many Europeans in Barbados as there were Africans, unlike the situation elsewhere, and this may have hastened the slaves' acquisition of metropolitan, rather than pidgin English.}

This may be valid in the case of Barbados due to the number of indentured Irishman and poor white colonists who worked the sugar fields with the African slaves, but it is perhaps a hasty conclusion to draw in the case of New Providence where certain occupations precluded high levels of interaction between the races.

Differences in occupation led to differences in access to the European model and thus created variations in the acculturative process within a community. According to Alleyne (1980),

\section{....... this (slave) society was hierarchically structured in terms of occupation, privileges, and access to the culture of the masters. This produced a certain cultural behaviourial differentiation in the slave population, among whom language differences must have been highly significant.}

Domestics who were placed in close contact with the European model retained African continuities for a relatively short time and acquired a system which was close to the European model, while fieldslaves who were far removed from contact with the European and whose social interactions were largely confined within the group acquired a system which was greatly influenced by their native language i.e. a creole.

Although the occupational stratification in New Providence had been less rigid than in the classical plantation society, there were jobs such as salt-raking, wood-cutting and planting and harvesting crops that would have been manned exclusively by a slave labour force. However such jobs were of a seasonal nature and did not result in the degree of isolation from an English model equal to that of the field slaves in the sugar colonies.

Salt-raking was the most labour intensive and entailed gangs of slaves removing to one of the salt islands (Turks, Rum Cay and Exuma) for months to rake salt. During this time they were isolated and communication was largely confined within the group, however on their return to New Providence they were employed in wood-cutting, field work or wrecking, and these activities brought them into close contact with their English-Speaking owners and Bermudian seaman. So although they were employed in jobs assigned exclusively to slaves, the nature of the job required communication outside the groups in which they worked and their small numbers meant more access to the English models than the large gangs of field slaves working the sugar plantations. This class of slaves in New Providence had least access to English, but it was not so restricted as to prevent some degree of acculturization, although compared to the slaves working in Nassau, their rate of language shift would be slow. 
A comparison of slave holdings in New Providence and Jamaica illustrates the differences in size between a non-plantation and a plantation economy.

TABLE 2 (i)

\section{Slave Holdings in New Providence 1731}

(Calculated from a list of inhabitants with numbers of slaves in a report from the Governor to the Council of Trade and Plantations. Calendar of State Papers).

\begin{tabular}{|c|c|}
\multicolumn{1}{c}{ Number } & Unit \\
\hline 2 & $30+$ \\
0 & $20-29$ \\
5 & $10-19$ \\
71 & $1-9$ \\
\hline
\end{tabular}

TABLE 2 (ii)

\section{Slave Holdings in Jamaica 1674 - 1701}

(Dunn 1972. An account of property of 198 planters)

\begin{tabular}{|c|c|}
\hline Number & Unit \\
\hline 54 (sugar plant.) & 63 (approx.) \\
8 (ranches) & 16 (approx.) \\
20 (indigo plant.) & 13 (approx.) \\
7 (cotton) & 12 (approx.) \\
109 (unidentified) & 8 (approx.) \\
\hline
\end{tabular}

The distribution per inhabitant for New Providence does not necessarily equate with a slave unit work force as any owner might have slaves occupying mariner and/or domestic positions. What we can infer is that the average subsistence farm was small and required no more than nine slaves. The significant difference is in the size of the slave holdings; the non-plantation economy never warranted large groups of field slaves who were largely isolated from an English model and confined to societal relations and communication within the group as did Jamaica and other sugar colonies. Drivers and overseers as intermediaries between master and field slave, slave quarters removed half a mile from the master's house were not a part of the non-plantation economy. The field slaves of New Providence were not field slaves in the plantation sense; their small numbers and the seasonal nature of their jobs fostered interaction with other 
groups which meant that even if a creole was established, it would not be as Africanized or as stable as that of their counterparts in Jamaica and linguistic acculturization would be a slow but ongoing process.

The town of Nassau at this time consisted of one unpaved road with houses, shops and a few public buildings on one side, and docks and the open harbour on the other. Government officials, merchants, shipbuilders, carpenters, pilots and fishermen lived in the town area and their slaves who largely occupied domestic and mariner positions lived within or behind their owner's house (see Saunders 1985). Since most of the inhabitants were seamen, a large number of slaves were crew members on fishing, wrecking, trading and privateering voyages. Slaves working as domestics and mariners in the city had ample access to the English model from day to day and the rate of linguistic acculturization for these slaves was rapid compared to those employed in farming, salt-raking and wood-cutting.

The crucial issue in terms of assessing the overall linguistic acculturative process of the slave society in New Providence would be the relative distribution of slaves in the various occupations, but since this information is not recorded until 1834 slave register returns, we have to speculate by looking at the state of the economy during this period. In times of peace the colony was destitute; export items were sporadic and few in number; the Public Treasury often lacked sufficient revenue to pay government officials. The only relief came in times of war. In a letter to the governor in 1760 some merchants of Nassau expressed the view, "... the business of Privateering is the most beneficial and almost the only profitable trade carried on in these islands" (Craton 1986). Although many of the early colonists who received land did engage in small scale farming, it would seem that the business of agriculture was not a major concern to the majority of the inhabitants. A visitor to the island in 1784 remarked on the primitive farming methods, "Plowing was unknown and even hoeing was uncommon ... and the favourite tool was a stick" (Peters 1960).

Based on these observations, it would appear that the majority of slaves were employed in the city as domestics, mariners or stevedores and by virtue of their access to English, acquired a system which was closer to English than creole, while the minority of slaves who were relegated to rural activities and had limited access to an English model, acquired a creole system. This is in inverse proportion to Jamaican slave society where the majority of slaves were field slaves and acquired a creole system and the minority were domestics who acquired English.

Another factor that affected the emerging language of the slave society was the status of the imported slaves with regard to their place of birth; a distinction is made between 'bozal', a slave born in Africa and 'creole', a slave born in the New World. A bozal in the New World would have initially many transmissions from his native speech, the elimination of which would depend on his occupation. A creole slave would be at home at some point in the acculturative process, depending on the occupation of the family into which he was born (see Alleyne 1980). So that if a slave society were made up of bozal slaves, those with minimal access to the European model would establish a creole system. If the continued demand for slaves was supplied by bozal rather than creole slaves, the African continuities were continually reinforced and the creole system stabilized. However if the demand for slaves was supplied by creole rather than bozal slaves, the African continuities became weakened as successive generations of creoles moved further on in the acculturative process.

Imports for the first decade of sustained settlement in New Providence were mainly bozal slaves by way of private trade direct from Africa (see Table 3). It is not clear from the records whether those by way of Jamaica, Hispaniola and Barbados were bozal or creole. The imports of unknown status are few in number and of the total imports $95 \%$ were African born. 
TABLE 3

Slave Imports 1721 - 1729

Source Date Bozal Creole Unknown

\begin{tabular}{|l|r|r|r|r|l|}
\hline$(1)$ & 1721 & 295 & & & Guinea \\
C.O. & 1722 & & & 2 & Jamaica \\
23/12/pt 2 & 1726 & & & 15 & Hispaniola \\
& 1727 & & & Barbados \\
$(2)$ & 1728 & 55 & & 6 & $?$ \\
C.O. 23/3 & 1729 & 133 & & & $?$ \\
\hline Total & & $483(95 \%)$ & & $25(5 \%)$ & \\
\hline
\end{tabular}

In 1729 an act was passed that levied a duty of 1/6d (later changed to 6/-) per head for each bozal slave and three pounds for each creole slave. It was clearly in the interest of Bahamians to buy bozal slaves given the differential in taxes, and the analysis of the accounts of duties and taxes between the year 1734 - 1744 (see Table 4) shows that the imports were in fact predominantly African born and came by way of Jamaica, Carolina and other Caribbean countries.

\section{TABLE 4}

Slave Imports $1734-1744$

Calculated from accounts of duties and taxes C.O. 23/4/pt. 2).

\begin{tabular}{|c|r|r|r|}
\hline \multicolumn{1}{|c}{ Year } & Creole & Total \\
\hline 1734 & 4 & 2 & 6 \\
1735 & 2 & 2 & 4 \\
1736 & 7 & 1 & 8 \\
1737 & 33 & 3 & 36 \\
1738 & 11 & 1 & 12 \\
1739 & 22 & 6 & 28 \\
1740 & 35 & 7 & 42 \\
1741 & 3 & 1 & 4 \\
1742 & 5 & 3 & 8 \\
1744 & 109 & 5 & 114 \\
\hline \multirow{2}{*}{ Total } & $231(88 \%)$ & $31(12 \%)$ & 262 \\
\hline
\end{tabular}

Out of a total of 262 slave imports, $231(88 \%)$ were bozal slaves and $31(12 \%)$ were creole. If we compare these figures to the increase of 521 slaves between 1734-1744 (see Table 1), we can account for the increase by following breakdown: $44 \%$ bozal imports, $6 \%$ creole imports and $50 \%$ natural increase.

The overall picture that emerges for New Providence in this period is higher degrees of linguistic acculturization for all segments of the slave society than occurred in the sugar colonies as a result of an early decline in the African born segment of the slave society due to lack of demand and natural growth, a sea-faring economy with less rigid occupational structure, small slave holdings and a greater number of 
slaves with access to the English model.

The Afro-Bahamian contact situation was in marked contrast to Jamaica where slave imports increased from 4,000 per year to 10,000 per year in the eighteenth century (LePage 1960), completely swamping the white population by a ratio of

11.5:1. The nature of the plantation economy resulted in the majority of slaves living and working in large homogeneous groups, interacting exclusively among themselves with minimal access to the European model. These conditions favoured by a high retention of African continuities, repeatedly reinforced by massive bozal imports, and very slow rates of linguistic acculturization.

\section{THE LOYALISTS $1783-1834$}

The arrival of the Loyalists from Florida in 1783 - 1785 had a significant impact on all spheres of Bahamian life. Originally from Georgia and Carolina, these political refugees who had opposed the independence of the colonies from Britain were uprooted once again in 1783 when Florida was ceded back to Spain. They injected new life and energy into the flagging Bahamian economy by the introduction of cotton plantations in the southeast islands and by the influx of a professional and planter-merchant class into Nassau. Peters (1960) comments, "Probably no small city in the world had more merchants than had Nassau after the coming of the Loyalists."

It is estimated that a total of between $6,000-7,000$ Loyalists with their slaves emigrated to The Bahamas. This influx more than doubled the total population and trebled the black population, thereby increasing the relative proportion of slaves from one half to two thirds of the total. The increase in the population and the distribution of the Loyalists and their slaves is illustrated in Table 5 below.

\section{TABLE 5}

Population of The Bahamas in 1783 and 1786

$\begin{array}{lccrrrr} & \text { Whites } & \text { Negroes } & \text { Total } & \text { Whites } & \text { Negroes } & \text { Total } \\ \text { New Providence } & 755(30 \%) & 1739(70 \%) & 2494 & 1572(28 \%) & 4019(72 \%) & 5591 \\ \text { Eleuthera } & 476(60 \%) & 310(40 \%) & 786 & 486(60 \%) & 315(40 \%) & 801 \\ \text { Harbour Island } & 360(71 \%) & 144(29 \%) & 504 & 365(71 \%) & 149(29 \%) & 514 \\ \text { Exuma } & 17(53 \%) & 15(47 \%) & 32 & 66(9 \%) & 638(91 \%) & 704 \\ \text { Long Island } & 33(30 \%) & 78(70 \%) & 111 & 41(29 \%) & 99(71 \%) & 140 \\ \text { Cat Island } & 6(40 \%) & 9(60 \%) & 15 & 59(16 \%) & 305(84 \%) & 364 \\ \text { Crooked Island } & - & - & - & 20(5 \%) & 357(95 \%) & 377 \\ \text { Caicos } & 2(28 \%) & 5(72 \%) & 7 & 28(12 \%) & 214(88 \%) & 242 \\ \text { Turks Island } & 75(65 \%) & 41(35 \%) & 116 & 75(65 \%) & 41(35 \%) & 116 \\ \text { Abaco } & - & - & - & 282(42 \%) & 384(58 \%) & 666 \\ \text { Andros } & - & - & - & 2(3 \%) & 59(97 \%) & 61 \\ \text { Totals } & \text { 1722(42\%) } & 2341(58 \%) & 4058 & 2996(31 \%) & 6580(68 \%) & 9576 \\ & \begin{array}{l}\text { Source: Craton 1986(adapted) } \\ \text { (\%) indicates relative proportion of white and }\end{array} & & \end{array}$


In New Providence the Loyalists and their slaves doubled the total population and the relative proportion of black to white increased slightly ( $70 \%-72 \%$ of the total). More than half of the Loyalists immigrants and half the slaves settled in New Providence, the other half being dispersed among the islands to the south, mainly Exuma, Cat Island, Crooked Island, and Caicos. In the southeast islands the slave population outstripped the white population reflecting the introduction of the plantation economy. The northeast islands were not settled by the Loyalists and with minimal population growth over these years they remained predominantly white. The southeasst islands and New Providence with a predominantly black population stood in marked contrast to the northeast islands.

\section{New Providence}

It is not clear what factors determined the eventual blending of the speech varieties of the Loyalists' slaves and the Bahamian slaves since little is known about the Loyalists' slaves in terms of their status (bozal or creole) or their distribution through the islands.

Both Carolina and Georgia were involved in a direct slave trade in the 1750 s and since a number of Loyalists (professionals and merchants) had only become planters on moving to The Bahamas it might be assumed that they purchased slaves on the mainland before emigrating. Craton (1986) states that one third of the Loyalistsí slaves were African born but provides no evidence for such a claim.

Nassau became a thriving centre of commercial activity with the initial success of the cotton plantations and a more diversified economy created a range of positions in the mariner, artisan and domestic classes. By 1834, 47.64\% of the slave population in New Providence were domestics, and $11.91 \%$ mariners (Saunders 1985), which suggests rapid acculturization irrespective of the status of slave. Slaves in the city had a wider range of positions and more access to Englisì after the Loyalists' arrival.

A number of country estate plantations were established in New Providence and by 1785 eleven plantations were cultivating cotton. Along with the plantation economy the Loyalists introduced a new relationship between master and slaves. The field slaves worked in larger groups, they were supervised by an overseer (in many cases a black freeman) they lived at a considerable distance from the main house and were confined to the plantation estate. These aspects of plantation life suggests a much more rigid routine than that of field slaves prior to the Loyalists, and one which did not allow for the degree of interaction outside the slave unit nor for the degree of access to an English model.

Cotton cultivation was abandoned much earlier in New Providence than the southeast islands and planters turned to stock-raising and subsistence farming. Although manumissions increased after the decline of cotton and the provision ground system was introduced for slaves remaining on the plantation, this quasi-independent state resulted in less access to an English model as they worked on their own provision grounds for two or three days a week with little or no supervision. The plantation system generally restricted the decline in the slaves' access to English and promoted pockets of creole in the decayed country plantations of New Providence. This was in contrast to more rapid acculturization processes evident in the city.

In 1835 a governor in a letter to the Colonial office made the following comment about the language in Nassau: "The language spoken here by whites and blacks, is the English language and with a great deal superior to some of the common dialects in England" (C.O. 23/94).

\section{The Southeast Plantation Islands}

The emigration of the Loyalists and their slaves to the southeast islands infused commercial activities into the islands that were previously uninhabited, or sparsely populated. Although a plantation economy was established, it in no way resembled that of the Caribbean neither in the size of the population nor in the regime of work to which the slaves were submitted. A traveller through the southeast islands in 1803 remarked on the good health and high spirit of the slaves, attributing them to less intensive working conditions: 


\section{Their labour is allotted to them daily and individually, according to their strength; and if they are so diligent as to have finished it at an early hour, the rest of the day is allowed to them for amusement or private concerns (McKinnen 1804).}

The task system was considerably less arduous than the eighteen hour work day of the slaves in the sugar colonies.

On the other hand, these islands in terms of the relative proportions of black to white were the closest approximation to the sugar colonies that the colony ever had. If we consider the demographic strength of the slaves (see Table 5) on Crooked Island (95\%), Exuma (91\%), Caicos (88\%) and Cat Island $(84 \%)$, it is self-evident that the elimination of African influence or any degree of language shifting was minimized due to the restricted access to English. Planters departed as early as 1800 as a result of the cotton failure, and later as a result of emancipation, leaving their former slaves to live on their own.

The value of linguistic studies that these southeast islands have, is that they can possibly shed light on the eighteenth century plantation creole and on the ongoing debate about the genesis of Black English. Holm (1983) presents both historical and linguistic evidence to support the claim that Gullah and Bahamian are closely related creoles sharing an immediate ancestor in the eighteenth century creole of the southern American colonies. Based on the data from the southeast islands, Shilling (1984) argues that Bahamian dialect offers a link between more basilect creole varieties of the Caribbean and Black English of the United States. It seems quite clear that following the collapse of the plantation system, the southeast islands became centres of linguistic conservatism in a way similar to the maroons of Jamaica and Guyana. Removed from all contact with acculturative influences the former slaves and their descendants were better able to preserve African continuities long after they had been lost on the mainland.

\section{CONCLUSION}

In conclusion, the linguistic acculturative processes in the northeast islands, New Providence and the southeast islands varied considerably. The emergence of different systems in these areas was largely a result of differences in settlement patterns, in demographic ratios of black and white populations, and in social and economic development. These differences in linguistic acculturization were reinforced to varying degrees by the relative isolation of one settlement from another. In the absence of any records of eighteenth century slave speech, socio-historical evidence lends weight to a linguistic continuum which extended from a creole system in the southeast islands to an English dialect in the northeast islands with speech varieties in New Providence intermediate to these two extremes; some slaves in New Providence acquired a language that was more English than creole, and others a language that was more creole than English; but no slave in New Providence in the eighteenth century acquired an English system similar to that of the northeast islands and likewise no slave in New Providence acquired a creole similar to that of the southeast islands. Different socio-historical conditions favoured the retention of African continuities or the elimination of African continuities to a greater or lesser extent, giving rise to discrete systems in the northeast, New Providence and the southeast islands. 


\section{BIBLIOGRAPHY}

Albury, P. 1975. The Story of The Bahamas. London, Macmillian.

Alleyne, M. 1980. Comparative Afro-American. Karoma, Ann Arbour.

Craton, M. 1986. A History of The Bahamas. Canada, San Salvador Press.

Dunn, R. 1972. Sugar and Slaves. The University of North Carolina Press.

Hancock, I. 1970. "A Provisional Comparison of English-based Atlantic Creoles" in African Review 8:7:72

. 1980. "Gullah and Barbadian: Origins and

Relationships" in American Speech 55:17:72

Holm, J. 1983. "On the Relationship of Gullah and

Bahamian" American Speech Vol. 58:4

LePage, R. 1960. Creole Language Studies I

Jamaican Creole London: Macmillan.

McKinnen. D. 1804. A Tour Through the British West Indies

London: Black-Horse-Court.

Peters, T. 1960. The American Loyalists and the Plantation

Period in the Bahama Islands. Unpublished Dissertation. Florida.

Saunders, G. 1985. Slavery in The Bahamas. Nassau, The Nassau Guardian.

Shilling, A. 1984. "Black English as a Creole - Some Bahamian Evidence". Society for Caribbean Linguistics Occasional Paper No.18.

Whylly, W. 1789. A Short Account of the Bahama Islands. London. 


\section{AUTHOR}

Anne Lawlor, a Senior Lecturer in English and Linguistics at The College of The Bahamas is also Chairperson of the Humanities Division. Formerly, she served as Coordinator of the English Department.

Mrs. Lawlor's ongoing research interest spans two disciplines: Bahamian varieties of English/Creole and Bahamian history. She is currently engaged in researching the history of Harbour Island. This island was home to her father, dentist and historian, Paul Albury whose book Story of The Bahamas she is updating.

Mrs. Lawlor studied at McGill University where she received a Bachelor's degree in English. Post-graduate studies in Linguistics were undertaken at University College, London University, London. She also holds a Post Graduate Certificate in Secondary Education (P.G.C.S.E) from the Institute of London, London. 